\title{
How to protect yourself from Radiation?
}

\author{
Garima Choudhary*
}

Radiation student Vth Sem BSc. RT, Jayoti Vidyapeeth Women's University, India

Submission: September 25, 2018; Published: October 05, 2018

"Correspondence Address: Garima Choudhary, Radiation student Vth Sem BSc RT, Jayoti Vidyapeeth Women's University, India, Email: r771980@gmail.com

\section{Introduction}

Radiation protection also known as radiological protection International Atomic Energy Agency (IAEA) defined as the protection of people from harmful effect of exposure to ionizing radiation. Radiation exposure can be from a radiation source it may be due to sun rays mobile etc. Radiation protection is the reduction of expected dose and measurement of dose uptake. The concept of risk is an important one and it is essential that we reduce risk to patient and staff through the justification, optimization and limitation of Radiation exposure.

\section{Exposure Situation}

a) Planned exposure: -radiological protection planned in advance.

b) Emergency exposure: -unexpected situation which require urgent protection.

c) Existing exposure: -these can be caused or occur from naturally occurring radioactive isotopes.

\section{Personal Dosimeter Devices}

The dosimeters are device which measure personal dose which is taken by a person in radiation department.

Examples: - radiation protection

a) Film badge dosimeter

b) Thermoluminescent dosimeter

\section{General Principle of Radiation Protection}

International Commission on Radiological Protection (ICRP) advocates the principle of "as low as reasonably achievable "which accepts the same amount of radiation exposure may be evitable. ICRP also recommends that radiation exposure should base on the principle of time distance shielding justification optimization and dose limit.

\section{Objective of radiation protection}

The various regulatory bodies like the ICRP, the national commission for (NCRP) in America and atomic energy regulatory board in India recommend and lay down norms for radiation protection in various countries around the globe. The ICRP 1991 that " The overall objectives of radiation protection is to provide an appropriate standard of protection for a man without unduly limiting the beneficial practice giving rise to radiation protection" The NCRP in 1993 issued a similar statement that "the goal of radiation on protection is to prevent the occurrence of serious radiation induced (acute and chronic deterministic effect) in exposed person to a degree that is acceptable in relation to the benefits to the individual and to society from the activity that generate such exposure.

\section{Radiation protection from radiation exposure}

Three of the most basic and easy to follow principles of radiation protection are:-
i. Time
ii. Distance
iii. Shielding

i. Time

The total dose received by a radiation worker is directly proportional to the total time spent near the radiation source. Lesser the time spent near the source lesser will be radiation dose. As the time spent in radiation field increase the radiation dose received also increase. Hence minimum the time spent in any radiation field minimum will be the radiation.

\section{ii. Distance}

Increasing the distance between the individual and the source of radiation is an effective method of reduce exposure to radiation .as the distance from the source of radiation is increased the radiation dose level will decrease significantly minimizing the distance from the source of radiation is a particularly effective method of exposure radiation during mobile radiography and fluoroscopy procedure. The amount of exposure reduction can be calculated using the inverse square law. Which describe the relationship between distance and radiation intensity? The inverse square low states that the intensity of radiation at a given distance from a point source is inversely proportional to the square of the distance. 


\section{Cancer Therapy \& Oncology International Journal}

\section{iii. Shielding}

When maximum distance and minimum time do not ensure an acceptably low radiation dose adequate shielding must be provided so that radiation beam will sufficiently attenuated. The material that attenuates the radiation called shield and the shield will reduce exposure to patient and public.

Radiation shielding materials are used in variety of radiologic applications the three major types of radiation shielding materials are: -

a) lead electrolytic shielding, lead electrolytic shielding,

b) non-lead- or lead-free shielding.

The high density of lead makes it useful shield against x-ray and gamma -ray radiation.

\section{a. Lead composite shielding}

lead based composite blend radiation shielding garments are lighter than regular grade lead and are available with the same lead equivalency protective level.

\section{b. Non- lead- or lead-free shielding}

These are manufactured with additives and bind that are mixed with attenuating heavy metals this fall into the same category of material as lead that absorb and block radiation.

\section{General Guidelines of Dose Limitation}

i. Individual doses due to combination of exposures from all relevant practices should not exceed specified dose limit for occupational or public exposure.

ii. Different dose limits are specified for the radiation workers as the excepted benefits from them do while handling radiation will outweigh the small increase in risk.

iii. Pregnant radiation worker has to be protected so that fetus/ embryo is given the same radiation protection as given to public.

iv. Dose limits are not applicable for medical exposure as the benefits gained outweigh the harm (Table 1).

Table 1: Dose limitation for occupational worker and public.

\begin{tabular}{|c|c|c|}
\hline \multicolumn{4}{|c|}{ Dose limitation for occupational worker and public } \\
\hline Types of limit & Occupational & Public \\
\hline (Effective Dose) & $20 \mathrm{msv} /$ year & $1 \mathrm{msv} / \mathrm{year}$ \\
\hline 1.lens of eye & $150 \mathrm{msv} /$ year & $15 \mathrm{msv} / \mathrm{year}$ \\
\hline 2.Skin & $500 \mathrm{msv} /$ year & $15 \mathrm{msv} / \mathrm{year}$ \\
\hline 3.Hands and Feet & $500 \mathrm{msv} /$ year & $50 \mathrm{msv} /$ year \\
\hline 4.Pregnant women & $1 \mathrm{msv} /$ year & $1 \mathrm{msv} / \mathrm{year}$ \\
\hline
\end{tabular}

\section{Justification}

The procedure involving radiation is necessary for patient care and that the radiation dose from the procedure is accepted to do better than harm.in case of the individual patient justification normally involves both the referring medical practitioner and the radiologist.

\section{Optimization}

once examination is justifiable they must be optimized that should be done at lower dose with the maintaining efficiency and accuracy. Optimization of the examination should be both generic for the examination type and all equipment and procedure involved.it should be specific for the individual and include review of the whether or not it can be effectively done in a way that reduce dose for particular patient.

\section{To reduce the Radiation Dose}

Reduce the time spent near the x-ray source.

Increase the distance from $\mathrm{x}$-ray source.
Interpose a shielding material between $\mathrm{x}$-ray source and operator.

\section{Radiation Protection Accessories}

i. Lead eyeglass
a. Lead gloves
b. Lead thyroid collar
c. Lead apron

\section{Conclusion}

Ionizing radiation may affect any living tissue through which it passes, potentially leaving damage in its make many times radiation has lifesaving effects but for radiologist and radiologic assistant who uses it as a part of occupation radiation could have detrimental consequence it is possible for medical imaging and radio therapy professional to have long safe carrier when they monitor radiation exposure and employ the 3 radiation protection principles. Time, Distance, Shielding. 
This work is licensed under Creative Commons Attribution 4.0 License

DOI: 10.19080/CTOIJ.2018.12.555836
Your next submission with Juniper Publishers will reach you the below assets

- Quality Editorial service

- Swift Peer Review

- Reprints availability

- E-prints Service

- Manuscript Podcast for convenient understanding

- Global attainment for your research

- Manuscript accessibility in different formats ( Pdf, E-pub, Full Text, Audio)

- Unceasing customer service

Track the below URL for one-step submission https://juniperpublishers.com/online-submission.php 